\title{
The Ecological ICMS as Inducer in the Creation of Protected Areas in Brazil An Assessment of Policy in the States of Pernambuco, Paraná and Bahia
}

http://dx.doi.org/10.21527/2237-6453.2019.47.217-237

Recebido em: 2/7/2016

Aceito em: 19/12/2018

\author{
Luiz Honorato da Silva Júnior ${ }^{1}$, Beatriz Mesquita Jardim Pedrosa ${ }^{2}$ \\ Liedje Bettizaide Oliveira de Siqueira ${ }^{3}$, Monaliza de Oliveira Ferreira ${ }^{4}$
}

\begin{abstract}
The main objective of this paper is to evaluate the effectiveness of the ecological ICMS to induce the creation of conservation units in Brazil, by analyzing the results of this policy in the municipalities of the Brazilian states of Paraná, Pernambuco and Bahia. The average effect of treatment as empirical strategy was used for that purpose. This study has showed that the stage of development and population size of cities is important to explain the dynamics of protected areas. The Ecological ICMS in Paraná was found to present better results than those observed in Pernambuco, that the policy in this state can be a model for Bahia and other states wanting to implement such a policy.
\end{abstract}

Keywords: Ecological ICMS. Conservation units. Average effect of treatment. Brazil.

O ICMS ECOLÓGICO COMO INDUTOR NA CRIAÇÃO DE ÁREAS PROTEGIDAS NO BRASIL: UMA AVALIAÇÃO DE POLÍTICA NOS ESTADOS DE PERNAMBUCO, PARANÁ E BAHIA

\section{RESUMO}

O principal objetivo deste trabalho é avaliar a eficácia do ICMS-ecológico para induzir a criação de unidades de conservação no Brasil, analisando os resultados dessa política nos municípios dos Estados do Paraná, Pernambuco e Bahia. O efeito médio do tratamento como estratégia empírica foi utilizado para esse fim. $O$ estudo mostrou que o nível de desenvolvimento e tamanho da população das cidades é importante para explicar a dinâmica das áreas protegidas. Verificou-se que o ICMS Ecológico no Paraná apresenta melhores resultados que os observados em Pernambuco. Além disso, constatou-se que a experiência do Paraná pode servir de referência para a aplicação desta política em outros Estados brasileiros.

Palavras-chave: ICMS ecológico. Unidades de conservação. Efeito médio de tratamento. Brasil.

\footnotetext{
${ }^{1}$ Doutor em Economia pela Universidade Federal de Pernambuco (Ufpe). Professor da Universidade de Brasília (UnB). Iula_honorato@ hotmail.com

2 Doutora em Recursos Pesqueiros e Aquicultura pela Universidade Federal Rural de Pernambuco (Ufrpe). Pesquisadora da Fundação Joaquim Nabuco. mesquitabia@hotmail.com

${ }^{3}$ Doutora em Economia pela Universidade Federal de Pernambuco (Ufpe). Professora da Universidade Federal da Paraíba (UFPB). liedje_s@ yahoo.com

${ }^{4}$ Doutora em Economia pela Universidade Federal de Pernambuco (Ufpe). Professora da Universidade Federal de Pernambuco (Ufpe). monaliza.ferreira@ufpe.br
} 
Environment is regarded as public goods; so therefore, the existence of protected areas in socially optimal levels becomes unlikely without governmental intervention. Which the increasing opportunity cost of land and also the increasing demand for forest products, a socially optimal supply of protected areas is unlikely to exist without a public policy that encourages both its creation and conservation. The ICMS (a tax on the circulation of goods and service provision of interstate and intermunicipal transportation and communications) was established by the 1988 Brazilian Federal Constitution.

Article 158 incorporated the former ICM flat taxes (minerals, energy, fuels and lubricants) and taxes on transport (interstate) and communication. The Constitution also stipulates that the State is entitled to $75 \%$ of the amount collected, and the remaining $25 \%$ directed to the municipalities. Regarding the percentage that municipalities have the right to $75 \%$ must be passed on according to the economic criterion (Value Added Tax - VAT) and the other $25 \%$ according to a specific state law.

The Constitution delegated unlimited power to the states, allowing them to define the distribution model of $1 / 4$ of those resources, thus, giving them influence on their municipalities, as transfers of ICMS may be directed to areas identified as local priorities. This is the case of the ecological ICMS. Such legal provisions allow states to implement economic instruments for environmental management.

The ecological ICMS is not a new tax, it is a new form of distribution of the ICMS corresponding portion which belongs to municipalities. From pre-established criteria, it can target resources so that local development through environmental and/ or social assumptions is promoted, supplementing the distribution based on purely economic criteria. The ecological ICMS, in fact, is an intergovernmental transfer instrument that rewards the municipalities that promote actions of protection to the environment.

The main objective of this study is to evaluate the effectiveness of the ecological ICMS, based on the experience in the Brazilian states of Paraná and Pernambuco in comparison with the state of Bahia, which does not have such legislation.

Thus, this paper seeks answers on issues such as: Could the Ecological ICMS induce the creation of protected areas and conservation units in the states of Paraná and Pernambuco? What social and economic characteristics are capable of inducing the creation of new protected areas? What are the potential outcomes for the municipalities in the state of Bahia, if the ecological ICMS is implemented in this state? What are the main differences between state policies implemented in Paraná and Pernambuco and their implications for the effectiveness of the results? To answer these questions we used an estimate of the differences-in-differences (DIFS-in-DIFS) method, and found the effect of implementation of the ecological ICMS in the creation of new protected areas.

In addition to this brief introduction, this paper has four other sections. The second section discusses the creation of the ecological ICMS in Brazil by making a brief historical record on its implementation in the states of Paraná and Pernambuco, as well as the still on-going implementation in Bahia. The next section presents the methodology and database used. The fourth and fifth sections discuss the results and conclusions, respectively. 


\section{THE ECOLOGICAL ICMS IN BRAZIL}

Taxation has relevance because it finances the activities of the State assuring the supply of essential public services and also serving as an instrument of public policy. In the environmental area, command and control are the main instruments used in Brazil. The ecological ICMS, however, is an economic instrument of environmental management, created in a pioneering way in Brazil, with positive results for the environment (JATOBÁ, 2003).

It is an instrument of compensation or subsidy to municipalities that perform actions for the environment conservation. According to Nery (2006), ecological ICMS consists of an intra-governmental subsidy, characterized as tax incentives. It differs from other subsidies to encourage the public managers themselves instead of consumers and producers in the private market.

The literature on this subject shows two functions of this policy: (i) the compensatory function, by which the creation of protected areas, even if involving the loss of productive area, would generate revenue for the city -the ecological ICMS, then, would compensate these municipalities; (ii) the motivator function, which seeks to encourage positive actions in relation to the environment and sustainable development. The distribution of revenue by the solid waste criterion, such as the Environmental ICMS in Pernambuco, for example, encourages municipalities to create sanitary landfills and discontinued their dumps.

A great advantage of this policy is the possibility of regionalization of social demands. Each state can fit the criteria for distribution of ICMS to their local situation. Frame I shows the diversity of environmental criteria used for distribution of ICMS in the Brazilian states where legislation for the ecological ICMS exists.

Frame I - Laws of ecological ICMS in Brazil, Year 2010

\begin{tabular}{c|c|c|l|c}
\hline UF & $\begin{array}{c}\text { Original } \\
\text { Law }\end{array}$ & $\begin{array}{c}\text { Changes } \\
\text { in Law }\end{array}$ & \multicolumn{1}{|c}{ Environmental Criteria } & $\%$ \\
\hline PR & 1991 & $\begin{array}{c}1993 ; \\
1996 ; \\
1997 ; \\
2007\end{array}$ & Protected Areas: UCs, indigenous lands, Other & Public drinking water sources \\
\hline SP & 1993 & 2008 & $\begin{array}{l}\text { Units of nature conservation: ecological station, biological } \\
\text { reserve, state park, wildlife area in an environmentally } \\
\text { protected area, forest reserve area of environmental } \\
\text { protection, natural area tumbled, sustainable development } \\
\text { reserves and extractive reserves. }\end{array}$ & 0,5 \\
\hline MS & 1994 & $2000 ;$ & $\begin{array}{l}\text { Conservation areas, areas of indigenous lands and public } \\
\text { drinking water sources. }\end{array}$ & 5,0 \\
\hline MG & 1995 & 2001 & $\begin{array}{l}\text { Index of environmental sanitation, sanitary landfills, } \\
\text { sewage treatment plants and composting plants. } \\
\text { Index of conservation of the municipality: conservation } \\
\text { units (public and private) and area of reservation. }\end{array}$ & 0,45 \\
Area of occurrence of dry forest & 0,45 \\
\hline RO & 1996 & 2009 & 0,09 \\
\hline AP & 1996 & & $\begin{array}{l}\text { Conservation units } \\
\text { Index Conservation of the city: municipal conservation } \\
\text { areas, state, federal and private }\end{array}$ & 5,0 \\
\hline
\end{tabular}




\begin{tabular}{|c|c|c|c|c|}
\hline RS & 1997 & & $\begin{array}{l}\text { Environmental preservation areas, indigenous lands and } \\
\text { areas flooded by dams }\end{array}$ & 7,0 \\
\hline \multirow{2}{*}{ MT } & \multirow{2}{*}{2000} & \multirow{2}{*}{$\begin{array}{l}2001 ; \\
2004\end{array}$} & $\begin{array}{l}\text { Biological reserves, ecological stations, parks, natural } \\
\text { monuments, wildlife refuges, PRNP, wildlife reserves, } \\
\text { areas of ecological interest, APA, sustainable development } \\
\text { reserve, park roads, special protection areas and } \\
\text { indigenous reserves; }\end{array}$ & 5,0 \\
\hline & & & $\begin{array}{l}\text { Environmental sanitation: system collection, treatment } \\
\text { and water distribution systems, collection, treatment } \\
\text { and final disposal of solid waste and sanitary systems } \\
\text { breakdowns in the city. }\end{array}$ & 2,0 \\
\hline \multirow{4}{*}{ PE } & \multirow{4}{*}{2000} & \multirow{4}{*}{$\begin{array}{l}\text { 2001; } \\
\text { 2002; } \\
2003 ; \\
2007 ; \\
2009\end{array}$} & Conservation units & 1,0 \\
\hline & & & Solid waste & 2,0 \\
\hline & & & Garbage recycling plants & 1,0 \\
\hline & & & Watershed protection & 1,0 \\
\hline TO & 2002 & & $\begin{array}{l}\text { Municipal policy environment } \\
\text { Conservation units and indigenous lands } \\
\text { Control and fire fighting } \\
\text { Sanitation, water conservation, collection and disposal of } \\
\text { garbage } \\
\text { Conservation and land management }\end{array}$ & $\begin{array}{l}2,0 \\
3,5 \\
2,0 \\
3,5 \\
2,0\end{array}$ \\
\hline AC & 2004 & 2009 & $\begin{array}{l}\text { Areas of environmental conservation units, indigenous } \\
\text { areas, rural production units certified in accordance with } \\
\text { Law No. } 2025 \text { and rural properties with environmental } \\
\text { liabilities forest regularized }\end{array}$ & 1,0 \\
\hline CE & 2007 & $\begin{array}{l}2008 \\
2009\end{array}$ & Index Municipal Environmental Quality ${ }^{1}$ & 2,0 \\
\hline RJ & 2007 & & $\begin{array}{l}\text { Conservation units (45\%) } \\
\text { Environmental quality index of water resources (30\%) } \\
\text { Solid wastes (25\%) }\end{array}$ & 1,8 \\
\hline GO & 2007 & & $\begin{array}{l}\text { Supervision, defense, restoration and preservation of the } \\
\text { environment }\end{array}$ & 5,0 \\
\hline $\mathbf{P I}$ & 2008 & & $\begin{array}{l}\text { Strengthening environmental management - } \\
\text { Environmental Seal (categories A, B, C) }\end{array}$ & 3,0 \\
\hline
\end{tabular}

Source: Own elaboration from the information available in State Laws (several years).

In addition to those mentioned, the policy is being discussed and voted in at least five more states. It's important to highlight that in this frame, the symbols located in column named UF, denote fifteen states in Brazil that already have public policy called Ecological ICMS, where its signification, in order, is: Paraná (PR), São Paulo (SP), Mato Grosso do Sul (MS), Minas Gerais (MG), Rondônia (RO), Amapá (AP), Rio Grande do Sul (RS), Mato Grosso (MT), Pernambuco (PE), Tocantinas (TO), Acre (AC), Ceará (CE), Rio de Janeiro (RJ), Goiás (GO) and Piauí (PI).

Frame I shows several environmental criteria matching the characteristics and requirements of each state. Therefore, among the environmental criteria observed by both the pioneering states and the last ones to implement the policy, there is the presence of the criterion of "protected areas" or "conservation units" in all of them, thus the reason for choosing this criterion in this research. 


\section{The Pioneering Experience of Paraná}

Paraná was the first state in Brazil to create environmental criteria for the distribution of ICMS. It was the State Constitution, back in 1990 that brought the discussion of the ecological ICMS, even without naming it that way. In 1991 (Complementary Law n. 59), the ecological use of ICMS was implemented in order to compensate municipalities with economically productive land, which had been turned into protected areas. The Municipality of Piraquara, for example, had $90 \%$ of their territory protected, thus making the municipal administration press the State Government to implement the policy (RING, 2008).

Based on such experience policy, other states have also been incorporating the concept of environment to the Goods and Services Tax (ICMS). By then the ecological ICMS had proved to be a novelty and a legislative instrument for encouraging the municipalities to environmental conservation (VOLZ; BATISTA, 2010).

More recently, this instrument has assumed the motivator function characteristic especially in those states that consider criteria such as solid waste, which encourages municipalities to take care of their waste, thus reducing their polluting feature.

The quota distribution to municipalities in Paraná state is illustrated in Figure 1.

Figure 1 - History of Legislative Changes related to ICMS of the State of Paraná

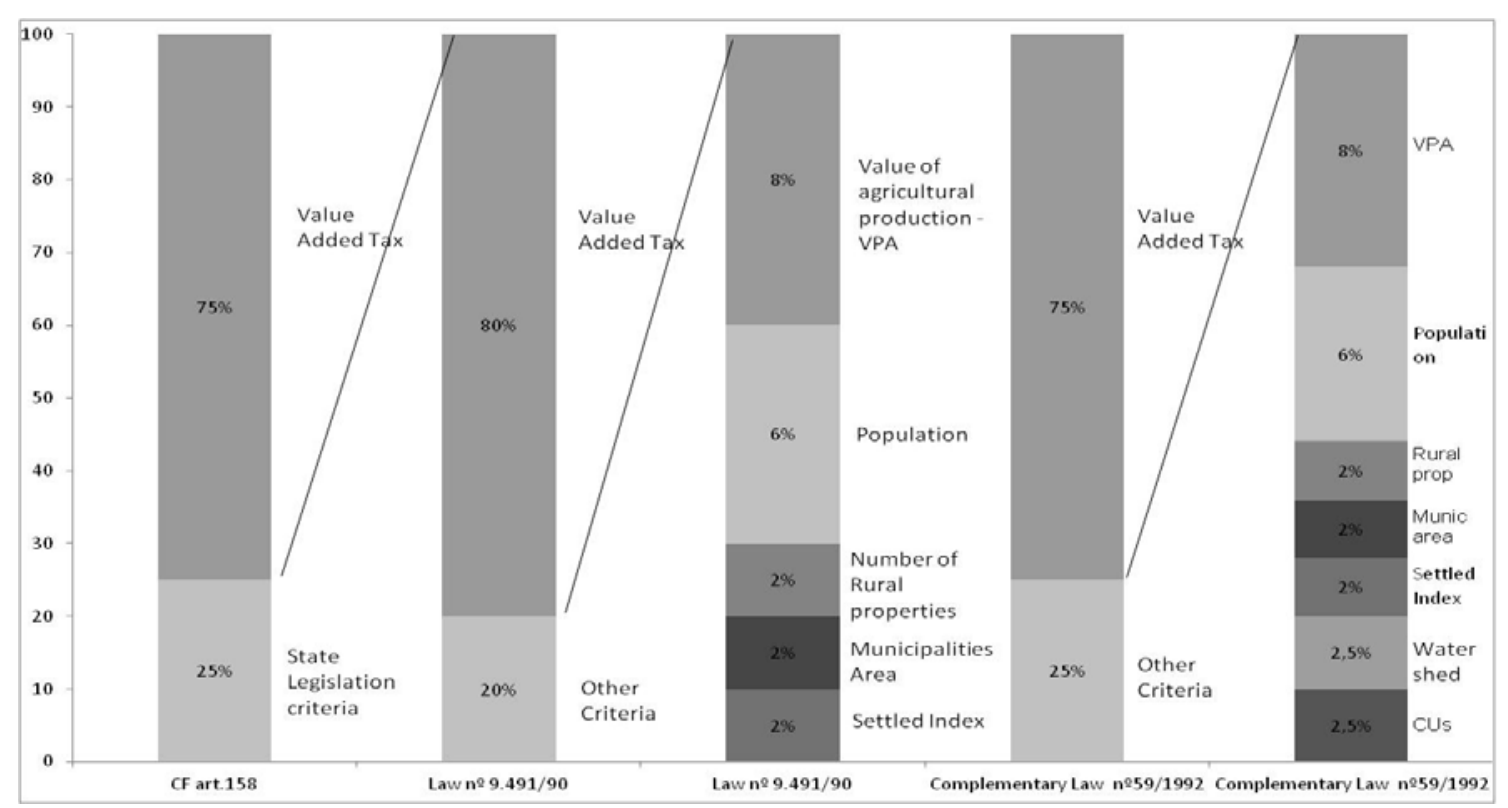

Source: Own elaboration from the information available in State Laws (PARANÁ, 1990, 1991).

It is clear that the shared percentages mostly benefit the agricultural production and settlement of people in rural areas. Taking into account the total amount allocated to municipalities, $10 \%$ is directed to factors directly related to rural areas. The bar chart shows firstly the criteria adopted by the Federal Constitution (75\% to the state and $25 \%$ to the municipalities), as well as the changes in the criteria by the state laws since the year 1990. 
Five percent of the total resources of the quota-share $(25 \%)$ of the municipalities come from environmental criteria, half from "protected areas" and half from "water supply sources". The percentage which municipalities are entitled to receive is based on quantitative and qualitative assessment data, which also differentiates Paraná from the other states.

Qualitative criteria are based on qualitative features, such as physical, biological and water resources qualities of a conservation unit and its surroundings; quality of planning, implementation, maintenance and management of a unit, equipment, personnel and training, research conservation units legitimacy for the community; additional analysis of the actions by the municipality in housing and urban development, agriculture, health and sanitation, among others (LOUREIRO, 2002).

Moreover, the category of conservation unit in conjunction with its area, proportional to the area of the city, characterizes the quantitative criterion. The conservation factors vary according to the biome, the area management categories, and the scope of legal responsibility.

For calculation purposes, in Paraná, the protected areas are areas of environmental preservation, ecological stations, parks, forests, forest reserves, forest gardens, Indian reserves, areas of relevant ecological interest by federal, state or municipal ordinances, which can be public or private property, called RPPNs (Complementary Law 67/1993), and Special Areas of Regulated Use, so called "faxinais" in Brazil (Decree no. 3446/1997).

These areas need to be registered in the State Register of Protected Areas (Ordinance n. 263/98/IAP/GP). It is worth emphasizing that the concept of protected areas in Paraná is broader than the concept of conservation units that the majority of Brazilian states use to calculate the ecological ICMS (including Pernambuco).

Several authors have analyzed the course of this policy in Paraná (LOUREIRO, 2002, VOLZ; BATISTA, 2010; RING, 2008), considering it a pioneering policy that generate positive results. The study conducted by Nery (2006) has made an economic and political analysis on the ecological ICMS, using cost-benefit perspective and concluding that the ecological ICMS is effective as a promoter of environmental preservation, but inefficient from the standpoint of economic compensation to municipalities.

Volz and Batista (2010) say the law of Paraná had international repercussion, since its recognition by the United Nations (UN) when it received the Henry Ford award for being one of the world's top ten projects in the area of ecology in 1997. Ring (2008), has proposed a similar tax to be implemented in Germany after analyzing the ecological ICMS in Brazil. According to her Portugal also implemented fiscal transfers to municipalities, similarly to the ecological ICMS, for protected areas from 2007 onwards.

The increase in the creation of protected areas can be seen in Table I. The data for the year 2005 were taken Environmental Institute do Paraná - IAP/DIBAP (2011). 
Table I - Increase in Area of Conservation in Paraná

\begin{tabular}{l|r|r|r|r|r}
\hline \multicolumn{1}{c|}{ Total Areas } & \multicolumn{1}{c|}{$\begin{array}{c}\text { Until } \\
1991\left(\mathrm{~km}^{2}\right)\end{array}$} & $\begin{array}{c}\text { Until June } \\
2005\left(\mathrm{~km}^{2}\right)\end{array}$ & Increase $(\%)$ & $\begin{array}{r}\text { Until January } \\
2011\end{array}$ & $\begin{array}{c}\text { Increase } \\
(\%)\end{array}$ \\
\hline Federal & $584.622,98$ & $694.186,26$ & 18,74 & $611.061,98$ & $-11,97$ \\
State & $118.163,59$ & $966.639,05$ & 718,05 & $1.205 .632,09$ & 24,72 \\
Municipal & $8.485,50$ & $227.873,81$ & $2.585,45$ & $289.030,80$ & 26,84 \\
Indigenous Lands & $81.500,74$ & $83.245,44$ & 2,14 & $77.811,79$ & $-6,53$ \\
RPPN & 0 & $37.149,77$ & - & $50.509,56$ & 35,96 \\
Faxinais & 0 & $16.132,54$ & - & $13.019,63$ & $-19,30$ \\
Permanent Preservation & 0 & $17.107,69$ & - & - & - \\
Areas & 0 & $16.697,73$ & - & - & - \\
Legal Reserve & 0 & $1.101,62$ & - & - & - \\
Special sites & 0 & $3.245,62$ & - & & - \\
Other Forests Connection & $792.772,81$ & $2.062 .229,77$ & 160,1287 & & - \\
\hline TOTAL & & & & - \\
\hline
\end{tabular}

Source: Authors' calculations. Data from the Department of Conservation, IAP/Dibap (2011).

The data for the year 2011 were calculated according to the information distribution of the VAT, provided by the IAP/ Dipad (2011), in which the total area may be underestimated, since there are qualitative criteria that can prevent the conservation unit from fitting the ecological ICMS in a given year. Data were not analyzed for the categories that are not included in the table.

Therefore, an increase in the creation of state and local conservation units, especially in the creation of RPPNs (35.96\%) compared to 2005 is noticed. In 2011, Paraná had 206 Private Reserves of Natural Heritage (RPPN) at state level, and only nine at federal level, which shows the states encouragement of RPPNs.

According to Cegana, Takahashi e Vieira (2007), municipalities are the main drivers of RPPNs in Paraná. Since they are private areas located in the municipalities, this incentive is facilitated. After the establishment of RPPNs Decree (N. 1529/2007), which allows a municipality to transfer funds from ICMS to an association of RPPNs, this incentive has also become financial.

The ecological ICMS in Paraná has been an incentive to the creation of protected areas by the state and municipalities, which in political terms is a great result. Traditionally, these units are established and managed by the Federal Government, while the consequences are felt by local actors, which results in a lack of commitment with regard to protected areas. Since the UCs are created locally, it is considered that the results are more efficient.

\section{The Experience in Pernambuco}

The state of Pernambuco was the ninth state to create environmental bases for the distribution of ICMS, being the first in the Northeast Region of Brazil. The state innovated this concept when it created the socio-environmental ICMS that, in addition to environmental criteria, sought to encourage the social improvement of the municipalities. The precariousness of socio-economic characteristics verified in the State influenced that decision. 
In this State (Pernambuco), from the environmental perspective, those municipalities that have implemented systems for solid waste treatment receive such compensation, as well as those that maintain protected areas in their boundaries. The mentioned policy seeks to encourage municipalities to adopt actions aimed at maintaining the remaining forest, biodiversity and environmental quality of water supplies in areas already recognized by the federal, state and local governments.

The state legislation of Pernambuco, presented in Figure 2, seems to reflect a dynamic unfinished policy, after considering the various law modifications which occurred since its creation in 2000.

Figure 2 - History of Legislative Changes related to ICMS of the State of Pernambuco

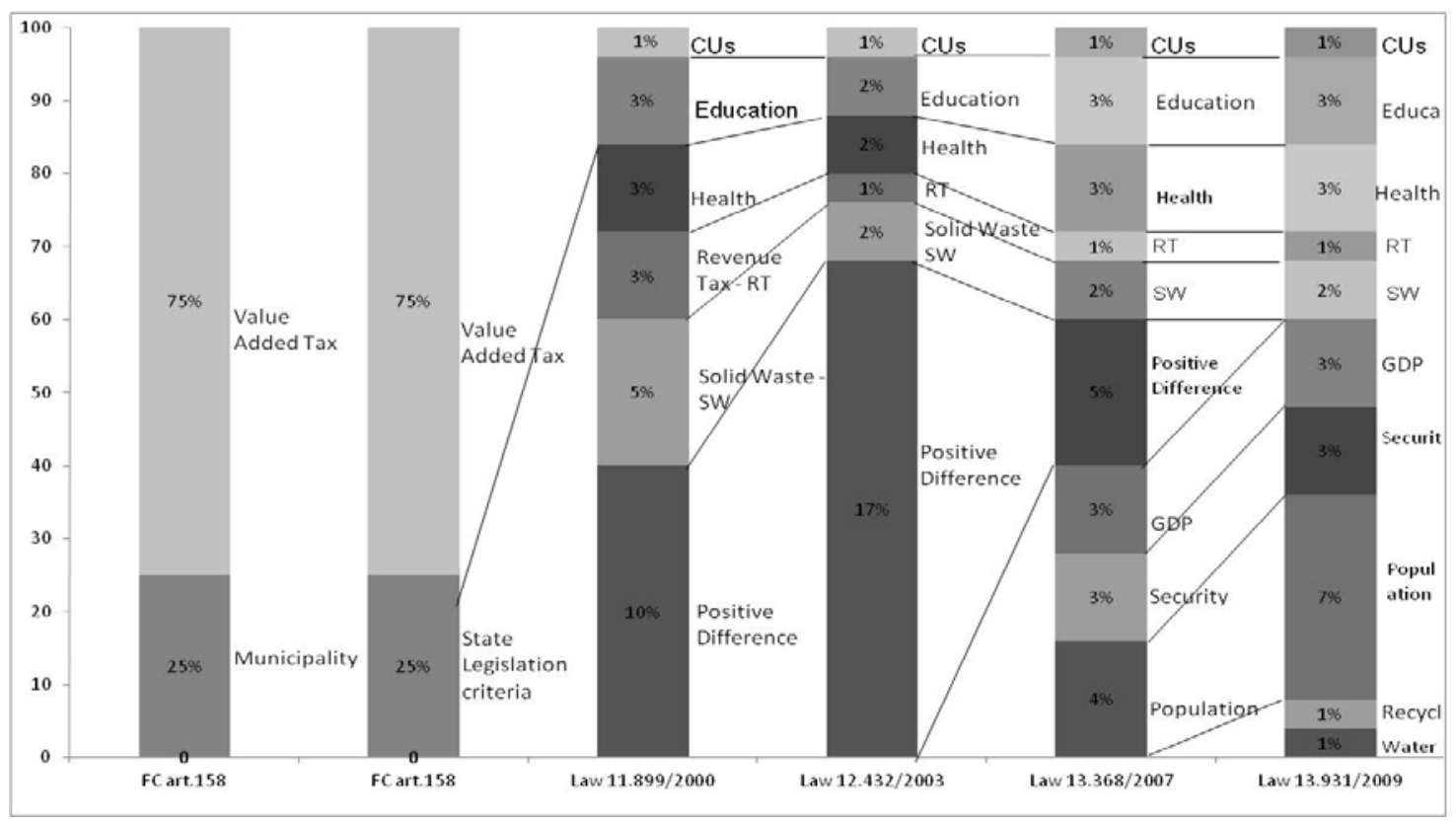

Source: Own elaboration from the information available in State Laws

(PERNAMBUCO, 2000, 2003, 2007, 2009).

The bars in the figure show firstly the allocating criteria by the Constitution, as well as the criteria for allocation of $25 \%$ to municipalities. The last four bars indicate the evolution of the criteria from the state laws in 2000, 2003, 2007 and finally in 2009, year in which it had not been implemented yet, representing a step forward in environmental issues, placing a further $2 \%$ of resource criteria for waste recycling and water supply sources.

According to Silva Júnior et al. (2010), the motivation for the constant changes in law, unlike what occurs in Paraná, comes from a constant attempt to redistribute income among the municipalities in the state. The formation of clusters of economic development, such as Suape Harbor Pole, tends to attract the resources from ICMS and would be an explanation for the recent law changes. In addition, the authors also mention that there was resistance from "losing" municipalities at the time of change in the law, which led the state to create the "positive difference" criterion, softening their financial loss. The percentage within this criterion was reduced with the successive changes in sharing the ICMS in the State. 
The ICMS policy analysis, with focus on environmental issues in the state of Pernambuco has no expression in the academic world, being represented by few studies (SILVA JÚNIOR et al., 2010; FERNANDES, 2005; PAULO; PEDROSA, 2009).

Silva Júnior et al. (2010) has a study in such policy in Pernambuco, concluding that there were no changes in the behavior of the municipalities before or after the implementation of socio-environmental ICMS, noting the low adherence to municipal policies. In 2008, a percentage of 31.5 of the municipalities were benefited by the conservation units criterion and only $10.32 \%$ by the solid waste criterion.

\section{The Method of the Policy in Bahia}

The state of Bahia is characterized by a large number of municipalities (417) and size $(567,295 \mathrm{~km} 2)$, located in the North-East of Brazil, with about 13 million inhabitants. The large number of municipalities can be one of the justifications for not using the ecological ICMS in the State before the year of 2010.

Despite being considered a pioneering state in environmental management, as well as having been host to the first State Council on Environment (Cepram), back in 1973, the implementation of the ecological ICMS in Bahia which was called "citizen ICMS", is an old bill that has not passed yet. The discussion about the new distribution of ICMS began in 2003 with the hiring of consultants to propose a series of economic instruments for environmental management for the state. These instruments were discussed in a seminar held in 2004 (SIEGA), where the proposed "citizen ICMS" was created.

After those discussions, a bill was proposed by Congressman José Nunes on March $8^{\text {th }}, 2006$ which is currently under discussion in the Committee on Constitution and Justice. According to the bill, $25 \%$ of the ICMS to be distributed to the municipalities as follows:

a. $40 \%$ considering the proportion of the population in each municipality and the total population of the state;

b. $25 \%$ considering the proportion between the geographical area of the municipality and the state's total area;

c. $30 \%$ distributed equally among all the municipalities that do not reach the preliminary index of 0.18001 ;

d. $5 \%$ considering the following environmental criteria:

(i) at least $50 \%$ of the total to be distributed to municipalities which systems of treatment or disposal of garbage or sewage, with operations licensed by the state environmental agency;

(ii) the remaining funds to be distributed based on the index of conservation of the city, considering the state federal and private conservation units as the municipality units should be registered, subject to parameters and procedures defined by the environmental agency.

The unimportance of environmental issues in the state of Bahia's proposal considered by Torres (2011) it's perceived in the low value to influence the municipal environmental management. In fact, when considering the $\$ 12$ billion total state revenue 
in 2010 (CONFAZ, 2010) divided by an approximate number of 100 municipalities to be contemplated with the environmental criteria of the citizen ICMS, the average figure of $R \$ 150,000.00 / y e a r$ per municipality would be obtained. This figure seems very low to encourage and compensate the opportunity costs as well as to promote environmental improvements, especially because of the high costs of the actions directed at environmental sanitation.

\section{METHODOLOGY AND DATA}

For assessment purposes, the municipalities of Paraná and Pernambuco were considered as intervention units when under the auspices of the ecological ICMS. The coverage of the assessment comprises the entire states of Paraná and Pernambuco, using municipalities in Bahia which do not follow ecological ICMS rules as comparison, as well as information from municipalities of Paraná and Pernambuco before the implementation of the ecological ICMS.

This paper proposes an analysis of counterfactual potential results. In terms of model potential outcomes, the analysis will proceed as follows:

$Y_{1 i s t}$ is the interest outcome of a municipality $i$ to the state $s$ during a time period $t$, assuming that the Ecological ICMS was implemented in that city;

$Y_{0 i s t}$ is the interest outcome from municipality $i$ to state $s$ during time period $t$; supposing the Ecological ICMS had not been used;

$T_{i} \quad$ is the dummy variable indicating the treatment status of the municipality. $T_{i}=1$ for the municipalities of Pernambuco and Paraná, which are under the auspices of the ICMS policy and $T_{i}=0$ for the cities that form the control group and which have or had not been reached by the policy.

In this study the dependent variable and object of research interest is measured by the number of protected areas in each municipality. If this variable was measured by the area or the percentage of protected areas within the municipalities, the results would be much more intuitive and the policy assessment would be more accurate. However, such data are not available. On the other hand, the results of estimation procedures can be interpreted as a probability of creating a conservation area, although not specifying what kind or from which municipal coverage area.

There is an interest in measuring the difference between these two results at three different points in time for municipalities. Since there is only one potential outcome, this claim is impossible. As a result, the "control group" is believed to be a good counter-factual.

\section{Data Base}

The data used, their source and the observed years for the evaluation are presented in Table II. The choice of those variables in order to investigate the effects of the policy took place by means of availability of data for the studied municipalities, as well as possibility of those variables presenting a good explanation for municipal decision-making and consequently good control variables. 
Table II - Description of Variables Used in Model, Data Source and Years Observed

\begin{tabular}{|c|c|c|c|}
\hline Acronym & Variable & Source of Data & Years Observed \\
\hline UC & Conservation Units & $\begin{array}{c}\text { IMA-BA/ } \\
\text { SECTMA-PE/ } \\
\text { IMA-PR }\end{array}$ & All available \\
\hline IDH & Municipal Human Development Index & IBGE & Years available \\
\hline IFDM & Municipal Development Index FIRJAN & FIRJAN & 2000 and 2006. \\
\hline Vote PV & $\begin{array}{l}\text { Number of votes cast for the Green Party in } \\
\text { the elections for councilor }\end{array}$ & IPEADATA & $\begin{array}{r}1992,2000 \text { and } \\
2008 .\end{array}$ \\
\hline Population & $\begin{array}{l}\text { Municipal Resident Population } \\
\text { (thousands) }\end{array}$ & IPEADATA & $\begin{array}{r}1991,2000 \text { and } \\
2007 .\end{array}$ \\
\hline $\begin{array}{l}\text { Per capita } \\
\text { income }\end{array}$ & $\begin{array}{l}\text { Municipal Income per Capita (thousands of } \\
\text { dollars, 2007) }\end{array}$ & $\begin{array}{l}\text { IPEADATA e } \\
\text { IBGE Cities }\end{array}$ & $\begin{array}{r}1991,2000 \text { and } \\
2007 .\end{array}$ \\
\hline Area & Territorial area of the municipality & IBGE & Years available \\
\hline Mayor & $\begin{array}{l}\text { Dummy Party of the Mayor is equal to the } \\
\text { Governor of the state or not }\end{array}$ & IPEADATA & $\begin{array}{r}1992,2000 \text { and } \\
2008\end{array}$ \\
\hline
\end{tabular}

Source: Own elaboration.

Such information is assumed to somehow influence decisions in the creation of CUs in federal states. The level of human development represented by the Human Development Index (HDI) and Firjam Municipal Development Index (IFDM) and the per capita income are believed to have a strong influence on the decision of creating environmental protected areas. Since social groups are able to achieve certain levels of development and social welfare, they have begun to have major concerns with the environment, either by use or existence value of environmental goods.

It was necessary to use two proxy variables for municipal development as the HDI was not available for the years when the Demographic Census (conducted every ten years by the Brazilian Institute of Geography and Statistics - IBGE) was not carried out. On the other hand, the IFDM was available for 2007, the year used for the third period of the panel. IFDM: Municipal Development Index, developed by Firjan (Industries Federation of the Rio de Janeiro State).

Population density and land area of the municipality may influence the creation of protected areas. Since the overcrowding, the environment has suffered greater pressure, individuals presumably coming to attach greater importance to environmental goods. On the other hand the municipal area is presented as potentially important, once a bigger availability of the territorial municipality suggests a higher possibility to the creation of protected areas.

The vote on the Green Party $(P V)$ variable refers to the number of votes for councilmen in the previous election period. This variable is a proxy of the environmental awareness of the citizens, since environmental conservation is the primary flag of the green party.

Finally, the "mayor" variable is a dummy variable that takes the value <<one >>" if the mayor of the municipality is from the same party of the governor, and <<zero>> otherwise. Such proxy tries to capture possible effects of information asymmetry, since there is a chance that the municipalities do not know the policy and therefore do not seek the creation of protected areas. The fact that the mayor of the municipality is from the same party of the governor, hypothetically eliminates this possibility. 


\section{Empirical Strategy}

The study hypothesis is that after the law that established the Ecological ICMS, the municipalities of the States of Paraná and Pernambuco began to seek improvements in their environmental indicators, from incentive mechanisms. Therefore, what is sought is to verify a causal relationship between the Ecological ICMS and the acceleration in the creation of protected areas in states that apply this policy. In the competitive environment for more resources, municipalities now have economic incentives to create protected areas and consequently increase their revenues.

Obviously, this study supports the hypothesis that municipal decision-makers always exercise attention to public management in order to maximize community welfare and social preferences, as well as the similar aspects of the cities in study.

\section{The Average Treatment Effect}

Estimating the impact of the implementation of the Ecological ICMS on the variable of interest to municipalities is going to happen, at first, by the presupposition of the occurrence of a natural experiment ${ }^{5}$. According to this hypothesis, the change in ICMS legislation of the State of Pernambuco would be a random event. It is hard to imagine that Paraná and Pernambuco have characteristics that distinguish them from other states and for this reason they have received such treatment; thereby, allowing for selection bias. It is known that the pioneering experience of Paraná and Pernambuco was caused by a political arrangement that favored such a vanguard (PERNAMBUCO, 2006).

If this assertion is correct, we can say that, except for the change in legislation, observation units (municipalities) in treated and control groups are identical in characteristics that may influence the interest variables. This fact allows us to attribute the distribution functions of the observed results for the controls on the potential results of treaties in the absence of treatment and, in particular, the moments of distributions.

Thus, assuming that the mathematical expectation is a linear operator, it is possible to estimate the average treatment effect on the units of observation.

\section{Estimation with Panel Data Fixed Effect: two or more periods}

The hypothesis of natural experiment was abandoned in a second moment. Since the simple difference of means produces biased estimates for non-randomized experiments, it becomes necessary to use regression methods to separate the effects of variables, either observable or unobservable, of pure effect of the change in legislation. To measure the effect of treatment on treated municipalities, covariates that seek to "control" their effects on outcomes, including those municipalities that comprise the "control group", will be considered.

According to Stock and Watson (2004) there are at least three reasons for the use of different estimators with additional regressors:

Wooldridge (2002) says that this type of result is known as naive as it only checks the statistical significance of a mean difference between the variables of treated and control interest groups, not considering other covariates that may influence the results significantly. 
i) Efficiency, because if the treatment is randomly assigned, the OLS estimator of $\beta$ in the multiple regression model (equation 3 shown below), is more efficient than the OLS estimator of the model with a single regressor (equation 1). The inclusion of additional determinants of $Y$ in equation (3) reduces the variance of the error term;

ii) Verification of randomness, because if treatment is not randomly assigned, and particularly if it is assigned so that $X_{i t}$ is related to estimator of differences, equation (1) is inconsistent and, more generally, has a probability threshold different from that of the estimator of differences with additional regressors (equation 3 ).

iii) Set to "conditional" randomness. The probability that the participant is assigned to the treatment group may differ from one group of individuals to another, ie, it may depend on the pre-treatment characteristics $X_{i t}$.

By the difference method, data are collected in the periods before and after the intervention considering differences within three periods. This is done through a regression with panel data. Thus, a linear regression is estimated by Ordinary Least Squares (OLS) for panel data with fixed effects in the municipalities.

According to Wooldridge (2002), a major advantage of this method is that the panel data allow us to consistently estimate treatment effects without the assumption of ignoring the treatment and without an instrumental variable. In addition, this method provides treatment responses varying over time and is not correlated with unobservable variables that vary over time and affect the response.

Using this method, the effects of the unobservable factors that influence the outcome variables are assumed to remain constant over time. Moreover, it is assumed that the treatment effect is additive, so that a linear function is able to capture the real effect. The equations describing the behavior of the variables of interest are expressed below:

$$
\begin{aligned}
& Y_{i s t}=\alpha+\beta T+u_{i t} \\
& Y_{i s t}=\alpha+\theta_{i}+\gamma t_{i}+\beta T+u_{i t} \\
& Y_{i s t}=\alpha+\theta_{i}+\gamma t_{i}+\beta T+\delta X_{i t}+u_{i t}
\end{aligned}
$$

where:

$Y_{i s t}=$ is the difference between the number of protected areas in the municipality during years $\mathrm{t}, \mathrm{t}-1$ and $\mathrm{t}-2$;

$\alpha$ is the intercept term;

$\theta_{i}$ includes the fixed effect specific to the municipality $i$;

$\gamma$ is the coefficient measuring the effect of time dummy;

$\beta$ includes the impact of a public policy on the variable of interest;

$\delta$ is the coefficient vector associated with the independent variables;

$X_{i t}$ is the independent variables matrix for each municipality $i$, during time $t$;

$u_{i t}$ is the error term;

Equations (1), (2) and (3) represent, respectively, the regressions with a single regressor, the inclusion of time and state dummies and regression with additional regressors, all with estimates of differences- in- differences. 
Also in Stock and Watson (2004), the estimators of differences-in-differences have two potential advantages over a single difference estimator, namely:

Efficiency. Some of the unobservable determinants of $Y_{\text {ist }}$ will be persistent over time for a particular individual;

Differences in $Y_{\text {ist }}$ are eliminated during the pre-treatment. If treatment is correlated to the initial level before the experiment, but $E$ (ui $\mid X i)=0$ in equation (3), $Y_{\text {ist }}$ differences estimator is biased, but the differences-in-differences estimator is not biased. By focusing on variation in Yist during the experiment, the estimator of differences-in-differences removes the influence of initial $Y_{i s t}$ that varies systematically between the treatment and control groups.

\section{Indicators Selection}

Regarding the estimation of the average impact on protected areas (conservation units), it is necessary to investigate the distribution among the municipalities that have these areas and are presented in parameterized Report of Conservation (BRAZIL/MMA, 2010) and those obtained from State Secretariats of Environment at those states. The State Secretariats are responsible for the registration of municipal conservation units in the state register of protected areas, besides the State units themselves.

The Ecological ICMS policy in Paraná began in 1991, while in Pernambuco the Social environmental ICMS began in 2004. These policies have been into action for several years, the information needed to measure the impact already in progress is believed to be sufficient to bring some results.

For municipalities in Bahia, which comprise the control group in this experiment because they have not had the Ecological ICMS, the results serve as potential outcomes. Once this policy is implemented the same effects noted for the pioneering states might be expected in Bahia.

\section{RESULTS AND DISCUSSION}

The main results of this research are now presented. Table III presents the descriptive statistics of main variables involved in the models. The results demonstrate the similarities and differences between the municipalities of the three federal states studied are observed.

Loureiro (2002) cites an increase of 97\% in the period between 1992 and 2000 with the number of municipalities in Paraná benefited by the ecological ICMS having increased from 112 to 221 (out of a total of 399 municipalities) since the creation of the tax.

In 2011, 297 municipalities under the criterion for protected areas benefited from the ecological ICMS. Regarding the variables that represent the structure of human development in the municipalities of each state, the index Firjan for development, as might be expected, reveals a huge supremacy of Paraná. In the three periods presented, the municipalities of Paraná were always around 2 decimal points above the municipalities of Pernambuco and Bahia. 
Similarly, the average per capita income among the municipalities of Paraná is always higher and the differences have increased over the years. Regarding the population average Pernambuco has the most populous municipalities compared to the other two states.

Concerning the votes for the candidates for mayor from the Green Party as an indicator of environmental consciousness, there is an enormous growth can be observed in the municipalities of Paraná and a lower average in the municipalities of Bahia. Pernambuco presents the highest historical average.

Table III - Descriptive Statistics of variables that make up the Model

\begin{tabular}{|c|c|c|c|c|c|c|c|c|c|}
\hline \multirow{2}{*}{ States } & \multicolumn{7}{|c|}{ Total area of protected areas $\left(\mathrm{km}^{2}\right)$} & \multirow{2}{*}{\multicolumn{2}{|c|}{$\begin{array}{l}\text { Total area of } \\
\text { States }\left(\mathbf{k m}^{2}\right)\end{array}$}} \\
\hline & \multicolumn{3}{|c|}{1991} & \multicolumn{3}{|c|}{2000} & 2007 & & \\
\hline Paraná & \multicolumn{3}{|c|}{$5.607,1364$} & \multicolumn{3}{|c|}{$19.606,12$} & $21.938,241$ & \multicolumn{2}{|c|}{$199.314,8$} \\
\hline Pernambuco & \multicolumn{3}{|c|}{41,0919} & \multicolumn{3}{|c|}{$1.528,78$} & 113,184 & \multicolumn{2}{|c|}{$98.311,6$} \\
\hline Bahia & \multicolumn{3}{|c|}{176,2484} & \multicolumn{3}{|c|}{$28.406,23$} & $5.156,619$ & \multicolumn{2}{|c|}{$567.295,7$} \\
\hline \multicolumn{10}{|c|}{ FIRJAN development índex } \\
\hline & \multicolumn{3}{|c|}{1991} & \multicolumn{3}{|c|}{2000} & \multicolumn{3}{|c|}{2007} \\
\hline & Min & Average & Max & Min & Average & Max & Min & Average & Max \\
\hline Paraná & 0,389 & 0,556 & 0,795 & 0,433 & 0,621 & 0,837 & 0,500 & 0,688 & 0,869 \\
\hline Pernambuco & 0,229 & 0,366 & 0,657 & 0,294 & 0,434 & 0,711 & 0,430 & 0,555 & 0,787 \\
\hline Bahia & 0,192 & 0,338 & 0,564 & 0,243 & 0,409 & 0,613 & 0,353 & 0,493 & 0,741 \\
\hline \multicolumn{10}{|c|}{ Population (in thousands of people) } \\
\hline & \multicolumn{3}{|c|}{1991} & \multicolumn{3}{|c|}{2000} & \multicolumn{3}{|c|}{2007} \\
\hline & Min & Average & Max & Min & Average & Max & Min & Average & Max \\
\hline Paraná & 1,2 & 26,2 & $1.315,0$ & 1,3 & 27,8 & $1.587,3$ & 1,4 & 29,9 & $1.797,4$ \\
\hline Pernambuco & 1.9 & 42,4 & $1.298,2$ & 2,1 & 45,9 & $1.422,9$ & 2,8 & 49,1 & $1.533,6$ \\
\hline Bahia & 3,3 & 28,6 & $2.075,3$ & 3,1 & 31,5 & $2.443,1$ & 3,5 & 33,9 & $2.892,6$ \\
\hline \multicolumn{10}{|c|}{ Vote for the Green Party councilor (in thousands of votes) } \\
\hline & \multicolumn{3}{|c|}{1992} & \multicolumn{3}{|c|}{\begin{tabular}{|c|c|}
2000 & \\
\end{tabular}} & \multicolumn{3}{|c|}{2008} \\
\hline & Min & Average & Max & Min & Average & Max & Min & Average & Max \\
\hline Paraná & 0 & 0,103 & 8,859 & 0 & 0,079 & 3,803 & 0 & 0,521 & 78,339 \\
\hline Pernambuco & 0 & 0,267 & 3,098 & 0 & 0,247 & 5,013 & 0 & 0,784 & 34,996 \\
\hline \multirow[t]{3}{*}{ Bahia } & 0 & 0,049 & 4,213 & 0 & 0,086 & 11,819 & 0 & 0,392 & 16,833 \\
\hline & \multicolumn{9}{|c|}{ Income per capita (Monthly average population, adjusted by the deflator of PNAD) } \\
\hline & \multicolumn{3}{|c|}{1991} & \multicolumn{3}{|c|}{\begin{tabular}{|c|c|}
2000 & \\
\end{tabular}} & & 2007 & \\
\hline Paraná & & 469,98 & & & 617,63 & & & 811,47 & \\
\hline Pernambuco & & 305,71 & & & 347,97 & & & 386,25 & \\
\hline Bahia & & 306,21 & & & 314,01 & & & 403,50 & \\
\hline
\end{tabular}

Source: Own elaboration.

The analysis of these variables allows for the confirmation of what was expected. The municipalities in Paraná have a significantly higher human development framework than the ones in Pernambuco and Bahia. If the development is an important component in the creation of protected areas in the municipalities, the inclusion of such covariables will be invaluable as control variables in the analysis of the impact that the Ecological ICMS can cause.

Next the results of regression analysis of the effect of the ecological ICMS in the creation of conservation units in the municipalities of Paraná and Pernambuco are presented. Table $\mathrm{V}$ presents the regression results of a sample consisting of the municipalities of the states in study. The same results are presented for regressions made with the full sample and with some variation between them. Thus, regressions will be made even with sub-samples combining Paraná (treated) and Bahia (control) and, finally, Pernambuco (treated) and Bahia (control). 
Table IV - The Effect of Ecological ICMS in the creation of conservation units in the municipalities of Paraná and Pernambuco

\begin{tabular}{|c|c|c|c|c|c|c|}
\hline Regressor & (1) & $(2)$ & (3) & (4) & (5) & $(6)$ \\
\hline Ecological ICMS & $\begin{array}{c}0,770 * * * \\
(0,050)\end{array}$ & $\begin{array}{c}0,369 * * * \\
(0,047)\end{array}$ & $\begin{array}{c}0,350 * * * \\
(0,085)\end{array}$ & $\begin{array}{c}0,342^{* * *} \\
(0,085)\end{array}$ & $\begin{array}{c}0,353^{* * *} \\
(0,085)\end{array}$ & $\begin{array}{c}0,349 * * * \\
(0,085)\end{array}$ \\
\hline IFDM / HDI & & & $\begin{array}{c}2,520 * * * \\
(0,344)\end{array}$ & $\begin{array}{c}2,311^{* * *} \\
(0,350)\end{array}$ & $\begin{array}{c}1,609 * * * \\
(0,362)\end{array}$ & $\begin{array}{c}1,624^{* * *} \\
(0,361) \\
\end{array}$ \\
\hline Per capita income & & & & $\begin{array}{c}0,346 * * * \\
(0,116)\end{array}$ & $\begin{array}{c}0,296 * * \\
(0,115)\end{array}$ & $\begin{array}{r}0,293 * * \\
(0,115) \\
\end{array}$ \\
\hline Population & & & & & $\begin{array}{c}1,409^{\mathrm{E}-6^{* * *}} \\
(0,000)\end{array}$ & $\begin{array}{c}1,413^{\mathrm{E}-6^{* * *}} \\
(0,000)\end{array}$ \\
\hline The municipal área & & & & & $\begin{array}{l}1,653^{\mathrm{E}-5} \\
(0,000)\end{array}$ & \\
\hline $\begin{array}{l}\text { Mayor together with } \\
\text { the Governor }\end{array}$ & & & & & $\begin{array}{l}-0,037 \\
(0,052)\end{array}$ & \\
\hline $\begin{array}{l}\text { Votes for Councilors } \\
\text { in PV }\end{array}$ & & & & & $\begin{array}{l}8,266^{\mathrm{E}-5} \\
(0,015)\end{array}$ & \\
\hline State effects & No & Yes & Yes & Yes & Yes & Yes \\
\hline Time effects & No & Yes & Yes & Yes & Yes & Yes \\
\hline $\mathrm{R}^{2}$ & 0,080 & 0,093 & 0,110 & 0,113 & 0,130 & 0,129 \\
\hline F-test & $\begin{array}{c}237,363 \\
(0,000)\end{array}$ & $\begin{array}{l}55,296 \\
(0,000)\end{array}$ & $\begin{array}{l}55,920 \\
(0,000)\end{array}$ & $\begin{array}{l}49,351 \\
(0,000)\end{array}$ & $\begin{array}{l}36,582 \\
(0,000)\end{array}$ & $\begin{array}{l}50,121 \\
(0,000)\end{array}$ \\
\hline
\end{tabular}

Standard errors in parentheses with $p<0,10=*, p<0,05^{* *}$ e $p<0,01 * * *$.

\section{Source: Own elaboration.}

Table IV presents the results of six models. First, the effects of ecological ICMS are checked without the use of dummy variables to control the state and time effects and without the use of any co-variate (model 1). The results of this regression are equivalent to results of a difference between averages of that variable between the treated and control groups.

The literature deals with this outcome as a naive result, since the average difference is made without taking into account the effects of covariates thought to be important for the creation of protected areas, and the creation of Ecological ICMS itself within the state. Based on this first analysis, the municipalities benefited by the Ecological ICMS tend to create more protected areas than those who are not subject to this policy, at $77 \%$ higher chance ${ }^{6}$.

The dummy variables of state and time effects are placed in the second model (2). Note that the level of statistical significance is preserved ( $p<0.01)$; however, the effect loses magnitude since much of the effect of creating protected areas is explained by the inclusion of these variables that capture a set of features omitted in the previous model and corrects the bias of omitted variables.

Models (3) and (4) introduce the IFDM and income per capita. Both models show the importance of the level of development and income levels of the population in the creation of conservation units. Both covariates were positive and statistically significant. It is noticed that the population that does not have their basic survival needs attended to presents low development level and should have less concern about of environmental

\footnotetext{
${ }^{6}$ It is important to note that the creation of conservation units is not only the municipalities' responsibility; it can also be done at Federal and State levels. It is necessary to remember that municipalities often have political influence on those decisions.
} 
conservation issues. Thus, people with lower educational development, poor access to health services and less wealth will be less encouraged to conserve the environment as it quite possible assumes the characteristics of luxury goods for this population segment.

The fifth model introduces the population, the area of the municipality, the mayor dummy, allied to the votes for governor and council from the Green Party. Only the population variable was statistically significant, while the other variables were not. This result shows that in a larger number of inhabitants, probably with greater population density and agglomeration effects, landscape and green are of utmost importance. On the other hand, there is no evidence of asymmetric information, since the mayor variable allied to the governor one was not statistically significant.

The sixth and final model in Table IV presents the results of the impact of the Ecological ICMS on all other covariates that showed statistical significance. It appears that the Ecological ICMS was responsible for the creation of conservation units at 0.349, ceteris paribus, in the municipalities covered by this policy, controlled by all statistically significant variables. Note that the first six models presented corroborating evidence of the efficiency of the law, especially in an environment of positive human development.

Then, the results are presented in a new set of estimates, using a new database. The six previous regressions have been remade this time; however, a new sub-sample was used, leaving out the municipalities of Pernambuco. The idea was to verify so distinguish policies in the state of Paraná and Pernambuco, always using the same control group.

Table $V$ presents the results of the regression of the effect of the Ecological ICMS in the creation of conservation units in the municipalities of Paraná. In general, the same difficulties of adjusting the regression verified in $\mathrm{R}^{2}$ of the previous models are observed. However, the F-test remains statistically significant.

Table V - The Effect of Ecological ICMS in the creation of conservation units in the municipalities of Paraná

\begin{tabular}{|c|c|c|c|c|c|c|}
\hline Regressor & (7) & (8) & (9) & (10) & (11) & (12) \\
\hline Ecological ICMS & $\begin{array}{r}0,882 * * * \\
(0,055)\end{array}$ & $\begin{array}{r}0,614 * * * \\
(0,106)\end{array}$ & $\begin{array}{r}0,641 * * * \\
(0,106)\end{array}$ & $\begin{array}{r}0,615^{* * *} \\
(0,106)\end{array}$ & $\begin{array}{c}0,620 * * * \\
(0,106)\end{array}$ & $\begin{array}{r}0,614^{* * *} \\
(0,106)\end{array}$ \\
\hline IFDM / HDI & & & $\begin{array}{r}1,812 * * * \\
(0,389)\end{array}$ & $\begin{array}{r}1,642 * * * \\
(0,397)\end{array}$ & $\begin{array}{c}1,239 * * * \\
(0,407)\end{array}$ & $\begin{array}{r}1,296^{* * *} \\
(0,405)\end{array}$ \\
\hline Per capita income & & & & $\begin{array}{r}0,251^{* *} \\
(0,120) \\
\end{array}$ & $\begin{array}{l}0,227^{*} \\
(0,120) \\
\end{array}$ & $\begin{array}{l}0,219^{*} \\
(0,120) \\
\end{array}$ \\
\hline Population & & & & & $\begin{array}{c}1,062^{\mathrm{E}-6^{* * *}} \\
(0,000)\end{array}$ & $\begin{array}{r}8,863^{\mathrm{E}-7^{* * *}} \\
(0,000)\end{array}$ \\
\hline The municipal area & & & & & $\begin{array}{l}2,077^{\mathrm{E}-5} \\
(0,000)\end{array}$ & \\
\hline $\begin{array}{l}\text { Mayor together with the } \\
\text { Governor }\end{array}$ & & & & & $\begin{array}{l}-0,046 \\
(0,057) \\
\end{array}$ & \\
\hline Votes for Councilors in PV & & & & & $\begin{array}{l}-0,020 \\
(0,016) \\
\end{array}$ & \\
\hline State effects & No & Yes & Yes & Yes & Yes & Yes \\
\hline Time effects & No & Yes & Yes & Yes & Yes & Yes \\
\hline $\mathrm{R}^{2}$ & 0,105 & 0,113 & 0,122 & 0,124 & 0,131 & 0,130 \\
\hline F-test & $\begin{array}{c}260,491 \\
(0,000) \\
\end{array}$ & $\begin{array}{l}70,392 \\
(0,000) \\
\end{array}$ & $\begin{array}{l}61,177 \\
(0,000) \\
\end{array}$ & $\begin{array}{l}51,783 \\
(0,000) \\
\end{array}$ & $\begin{array}{l}33,271 \\
(0,000) \\
\end{array}$ & $\begin{array}{l}46,993 \\
(0,000) \\
\end{array}$ \\
\hline
\end{tabular}

Standard errors in parentheses with $p<0,10=*, p<0,05^{* *}$ e $p<0,01^{* * *}$.

Source: Own elaboration. 
Those estimated coefficients of the Ecological ICMS from the first six models, remain positive and statistically significant; however, they appear with greater impact. These results can be understood as evidence that the policy in Paraná has more power in the inductive creation of Conservation Units than the one in Pernambuco. In fact, as seen above, the remuneration paid to municipalities in Paraná is larger than that given to the municipalities in Pernambuco. Of course, this difference in pay should be checked so that the difference in impact on previous models is almost double.

The behavior of the covariates is quite similar to that presented by previous models, confirming the importance observed in the development in the per capita income and population agglomerations that greater conservation action.

A third sample composition is also proposed in this paper. This time the sample has left out all municipalities in Paraná. The objective is to verify the impact of the policy in Pernambuco and its efficacy in relation to the control group; which is formed by the municipalities in Bahia. The proposed regression results are presented in Table VI.

Table VI - The Effect of Ecological ICMS in the creation of conservation units in the municipalities of Pernambuco

\begin{tabular}{|c|c|c|c|c|c|c|}
\hline Regressor & $(13)$ & (14) & $(15)$ & $(16)$ & $(17)$ & (18) \\
\hline Ecological ICMS & $\begin{array}{c}0,439 * * * \\
(0,066)\end{array}$ & $\begin{array}{c}0,146 \\
(0,090)\end{array}$ & $\begin{array}{c}0,028 \\
(0,087)\end{array}$ & $\begin{array}{c}0,045 \\
(0,087)\end{array}$ & $\begin{array}{c}0,066 \\
(0,083)\end{array}$ & $\begin{array}{c}0,085 \\
(0,083)\end{array}$ \\
\hline IFDM / HDI & & & $\begin{array}{c}3,308 * * * \\
(0,275)\end{array}$ & $\begin{array}{c}3,087^{* * *} \\
(0,282)\end{array}$ & $\begin{array}{c}1,855^{* * *} \\
(0,286)\end{array}$ & $\begin{array}{c}1,913^{* * *} \\
(0,287)\end{array}$ \\
\hline Per capita income & & & & $\begin{array}{c}0,310^{* * *} \\
(0,090) \\
\end{array}$ & $\begin{array}{c}0,297 * * * \\
(0,085)\end{array}$ & $\begin{array}{c}0,293 * * * \\
(0,086) \\
\end{array}$ \\
\hline Population & & & & & $\begin{array}{c}1,152^{\mathrm{E}-6^{* * *}} \\
(0,000)\end{array}$ & $\begin{array}{c}1,816^{\mathrm{E}--^{* * *}}(0,000) \\
\end{array}$ \\
\hline The municipal área & & & & & $\begin{array}{l}4,827^{\mathrm{E}-6} \\
(0,000)\end{array}$ & \\
\hline $\begin{array}{l}\text { Mayor together with the } \\
\text { Governor }\end{array}$ & & & & & $\begin{array}{c}-0,001 \\
(0,041) \\
\end{array}$ & \\
\hline Votes for Councilors in PV & & & & & $\begin{array}{c}0,108 * * * \\
(0,019)\end{array}$ & \\
\hline State effects & No & Yes & Yes & Yes & Yes & Yes \\
\hline Time effects & No & Yes & Yes & Yes & Yes & Yes \\
\hline $\mathrm{R}^{2}$ & 0,025 & 0,055 & 0,128 & 0,134 & 0,216 & 0,201 \\
\hline F-test & $\begin{array}{l}44,238 \\
(0,000)\end{array}$ & $\begin{array}{l}25,450 \\
(0,000)\end{array}$ & $\begin{array}{l}50,936 \\
(0,000)\end{array}$ & $\begin{array}{l}44,708 \\
(0,000)\end{array}$ & $\begin{array}{l}47,784 \\
(0,000)\end{array}$ & $\begin{array}{l}62,453 \\
(0,000)\end{array}$ \\
\hline
\end{tabular}

Standard errors in parentheses with $p<0,10=*, p<0,05^{* *}$ e $p<0,01 * * *$.

Source: Own elaboration.

From that table, there is a better fit, even in small models. However, the models resist the F-test. This time, smaller magnitudes of impact of the Ecological ICMS in the creation of conservation units are observed. Even more so the variable was not statistically significant in five of the six proposed models (13-18), while the control variables show a similar pattern to the results verified previously.

The observation alone of the test of average differences (model (13)), brings the conclusion of the effectiveness of law in Pernambuco (naive); however, when controlled by the state and temporal effects and covariates, the average effect of treatment loses 
its explanatory power. Noteworthy is the variable "votes" of the city council for PV in model 17 in which it is tested. Its greatest importance may be reflecting the relevance of commitment to ecological issues in some municipalities of Pernambuco.

It is observed however, that these results provide evidence of policy ineffectiveness in Pernambuco, despite a greater proportional growth of protected areas. The intention to dissipate the resources of the Socio-environmental ICMS in Pernambuco can generate an ineffective policy for the environment instead of a solution to their problems. The state may lose the opportunity to contribute significantly to the conservation of important biomes contained in its territory.

For municipalities of Bahia that served in this study as a comparison group, there is a message of efficiency of the Ecological ICMS. There remains the sense that different designs of policy, of course, bring different efficacy results.

\section{CONCLUSIONS}

This study aims to investigate the effectiveness of the Ecological ICMS in the induction of new protected areas in Brazil. A pioneering law created in 1991 in the state of Paraná it has spread to dozens of other states, gaining personality, and in each one receiving different forms which, in principal, sought to respond to the local demands of each Federation Unit.

In Pernambuco, the law sought to include various items and was named Socio-environmental ICMS, but it seems to have lost focus and efficiency. Low pay to those municipalities that maintain protected areas in their territory seems to have reduced the interest of creating new protected areas in the State, when compared to what happened to Paraná, where protected areas were created in a more incisive way from paying better.

In general, there is evidence that the Ecological ICMS is effective in inducing the creation of conservation units. However, for that to occur, it is necessary that the policy makes the environmental conservation business profitable and pay the opportunity cost that municipalities have when such units are created satisfactorily. If the amount received by municipalities is not perceived as compensation, the policy may lose its effectiveness.

This aspect seems to have been certified. From the data regression the policy was observed to be more effective in the State of Paraná than in Pernambuco. In fact, when the policy was put to test in Pernambuco, it seemed not to correspond to the proposed objectives. The explanation for this failure seems to be the lack of policy focus, unlike what has been happening in Paraná.

An attempt to find a solution to the socio-environmental problems in Pernambuco seems to have led the policy to a collapse, since if the policy is ineffective in solving environmental problems, it may also be globally ineffective.

The importance of human development, income and settlements in environmental conservation in the cities studied was verified. Thus, the Ecological ICMS seems to be an important instrument for those municipalities that have not reached an appropriate 
level of development to boost their conservation actions. These results may help in proposing different policies to better remunerate poorer and less developed municipalities which therefore have difficulty to implement the Ecological ICMS policy.

One hypothesis for the poor outcome of the policy in Pernambuco and its consequent ineffectiveness would be asymmetry of information among municipalities. It is thought that many municipalities in Pernambuco do not even know about this law and therefore could not respond to incentives. There was no positive evidence of such asymmetric information among municipalities. The fact that the mayor is a supporter of the governor seems not to have generated better results in the creation of new protected areas neither in Paraná nor in Pernambuco.

In the case of the state of Bahia, this study shows potential results. If Bahia wishes to improve the municipalities' financial efficiency and improve environmental conservation, it should reflect on the possibility of accelerating the discussions and the implementation of the law that creates the Ecological ICMS in its territory. Moreover, if Bahia intends to implement an effective policy it should not make the same mistakes of its neighbors, but must listening attentively to what the pioneers of this policy have to say, especially about the magnitude of the amount to be directed to environmental issues.

Finally, if the country wants to improve the efficiency of municipal expenditures, as well as environmental conservation, one should seriously consider encouraging mechanisms for good environmental practices with distinct compensation to those municipalities that make best use of resources. The amount of such incentives should also be taken into account. In the case of Pernambuco, the state cannot continue to believe that the Ecological ICMS is a remedy for its social and environmental problems; the policy must be focused by increasing the remuneration in order to make it effective.

\section{REFERENCES}

BAHIA. Assembléia Legislativa do Estado da Bahia. Projeto de lei $n^{\circ} 76 / 2006$. Define os percentuais do ICMS cidadão relativos aos Municípios da Bahia. Salvador: Assembléia Legislativa do Estado da Bahia, 2006.

BRASIL. Ministério do Meio Ambiente (MMA). Portal do Ministério do Meio Ambiente. 2010. Disponível em: www.meioambiente.gov.br. Diversos acessos entre 2010 e 2011.

BRASIL. Constituição da República Federativa do Brasil. Brasília, 1988.

CEGANA, A. C. V.; TAKAHASHI, L. Y.; VIEIRA, F. G. D. Perfil das reservas particulares do patrimônio natural do Estado do Paraná. Acta Scientiarum Agronomy, v. 29, n. 2, p. 205-210, 2007.

CONFAZ. Conselho Nacional de Política Fazendária. Arrecadação de ICMS por Estado da Federação. 2010. Disponível em: http://www.fazenda.gov.br/confaz/boletim. Acesso em: 28 mar. 2011.

FERNANDES, A. C. A. Avaliação do ICMS como um instrumento de política pública de desenvolvimento sustentável no Estado de Pernambuco. 2005. 208 f. Dissertação (Mestrado em Geografia) - Universidade Federal de Pernambuco, Recife, 2005.

IAP/DIBAP. Instituto Ambiental do Paraná. Unidades de Conservação do Paraná. Disponível em: www. uc.pr.gov.br. Acesso em: 28 mar. 2011.

JATOBÁ, J. O ICMS como instrumento econômico para a gestão ambiental: o caso do Brasil. Santiago do Chile: Cepal, 2003.

LOUREIRO, Wilson. Contribuição do ICMS Ecológico à conservação da biodiversidade no Estado do Paraná. Curitiba, 2002. Tese (Doutorado) - Curso de Pós-Graduação em Engenharia Florestal, Universidade Federal do Paraná. Disponível em: http://www.floresta.ufpr.br/pos-graduacao/seminarios/wilson/contribuicao_do_icms.pdf.

NERY, M. A. ICMS Ecológico: análise do desenho brasileiro de um subsídio ambiental. 2006. 98 f. Dissertação (Mestrado em Gestão Econômica do Meio Ambiente) - Universidade de Brasília, Brasília, 2006. 
PARANÁ. Lei Complementar n 9.491/1990. Estabelece critérios para fixação dos índices de participação dos municípios no produto de arrecadação do ICMS. Diário Oficial do Estado do Estado do Paraná $n^{\circ}$ 3.609, Curitiba, 1990.

PARANÁ. Lei Complementar n 59/1991. Dispõe sobre a repartição de 5\% do ICMS, que alude o art. 20 da Lei $\mathrm{n}$ 0 9.941/90 aos municípios com mananciais de abastecimento e unidades de conservação ambiental, assim como adota outras providências. Diário Oficial do Estado do Paraná, Curitiba, 1991.

PARANÁ. Lei Complementar n 67/1993. Dá nova redação ao art. 2o da Lei Complementar nº 59, de 1 de outubro de 1991. Diário Oficial do Estado do Paraná no 3.927, Curitiba, 1993.

PARANÁ. Decreto n³.446/1997. Criada no Estado do Paraná, as Áreas Especiais de Uso Regulamentado Aresur. Diário Oficial do Estado do Paraná n $n^{\circ}$ 5.067, Curitiba, 1997.

PARANÁ. Decreto n ${ }^{\circ}$ 1.529/2007. Dispõe sobre o Estatuto Estadual de Apoio à Conservação da Biodiversidade em Terras Privadas do Estado do Paraná, atualiza procedimentos para a criação de Reservas Particulares do Patrimônio Natural - RPPN - e dá outras providências. Diário Oficial do Estado do Paraná $n^{\circ}$ 7.569, Curitiba, 2007.

PARANÁ. Portaria n 263/98/IAP/GP/1998. Regulamenta o Cadastro Estadual de Unidades de Conservação e Áreas Especialmente Protegidas - CEUC. Gabinete do Diretor Presidente do Instituto Ambiental do Paraná - IAP, 1998.

PAULO, F. L. L. P.; PEDROSA, I. V. O imposto sobre circulação de mercadorias e serviços - ICMS socioambiental como incentivo à melhoria das políticas públicas ambientais em nível municipal: um exame de caso no Município de Camaragibe, Pernambuco. Enfoque: reflexão contábil, maio/ago. 2009. p. 74-83.

PERNAMBUCO. Secretaria de Ciência, Tecnologia e Meio Ambiente. ICMS socioambiental: a experiência do Estado de Pernambuco. Recife: Sectma, 2006.

PERNAMBUCO. Lei $n^{\circ}$ 11.899/2000. Redefine os critérios de distribuição da parte do ICMS que cabe aos municípios, de que trata o artigo $2^{\circ}$, da Lei $n^{\circ} 10.489$, de 2 de outubro de 1990 , considerando aspectos sócio-ambientais, e dá outras providências. Diário Oficial do Estado de Pernambuco, Recife, 2000.

PERNAMBUCO. Lei no $12.432 / 2003$. Ajusta os critérios de distribuição de parte do ICMS que cabe aos Municípios, nos termos do art. 2을 da Lei no 10.489, de 2 de outubro de 1990, com a redação da Lei no 11.899, de 21 de dezembro de 2000, e da Lei no 12.206, de 20 de maio de 2002. Diário Oficial do Estado de Pernambuco, Recife, 2003.

PERNAMBUCO. Lei no 13.368/2007. Ajusta critérios de distribuição de parte do ICMS que cabe aos municípios, nos termos da Lei no 10.489, de 2 de outubro de 1990, e alterações. Diário Oficial do Estado de Pernambuco, Recife, 2007.

PERNAMBUCO. Lei no 13.931/2009. Introduz modificações na Lei $n^{\circ} 10.489$, de 2 de outubro de 1990, e alterações, relativamente a redefinições de critérios de distribuição de parte do ICMS que cabe aos Municípios. Diário Oficial do Estado de Pernambuco, Recife, 2009.

RING, I. Integrating local ecological services into intergovernamental fiscal transfers: The case of the ecological ICMS in Brazil. Land Use Policy, n. 25, p. 485-497, 2008.

SILVA JÚNIOR, L. H.; ROCHA, R. M.; PEDROSA, B. M. J.; SIQUEIRA, L. B. O.; SAMPAIO, Y. ICMS socioambiental: uma avaliação da política no Estado de Pernambuco. Revista Desenbahia, v. 7, n. 13, set. 2010.

STOCK, James H.; WATSON, Mark W. Econometria. São Paulo: Addison Wesley, 2004.

TORRES, E. O ICMS ecológico. Disponível em: www.jurisway.org.br. Acesso em: 28 mar. 2011.

VOLZ, H. E.; BATISTA, A. A. Representatividade do ICMS ecológico na conta de participação do ICMS e na receita líquida do município de Toledo-PR (2004-2008). Informe GEPEC, Toledo, v. 14, n. 1, p. 161-176, 2010.

WOOLDRIDGE, J. M. Econometric Analysis of Cross Section and Panel Data. Massachusetts: Massachusetts Institute of Technology, 2002. 